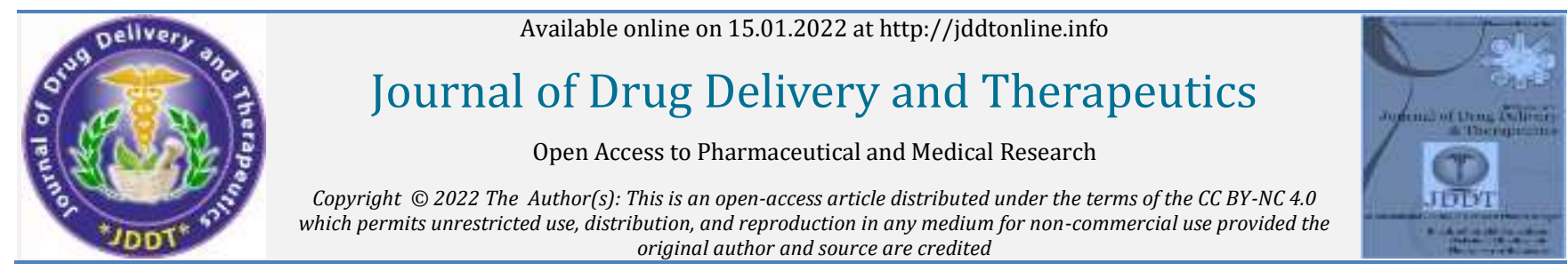

\title{
The Relationship between Antipsychotic Drug Use and Liver Enzyme Levels in People with Mental Disorders
}

\author{
Meiyanti*(1i), Lyfanni Fiesa Mulia, Pusparini (ii) \\ Faculty of Medicine, Universitas Trisakti, Jakarta, Indonesia
}

Article Info:

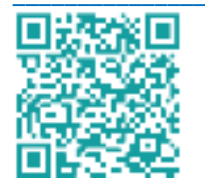

\section{Article History:}

Received 10 November 2021

Reviewed 18 December 2021

Accepted 23 December 2021

Published 15 January 2022

\section{Cite this article as:}

Meiyanti, Mulia LF, Pusparini, The Relationship between Antipsychotic Drug Use and Liver Enzyme Levels in People with Mental Disorders, Journal of Drug Delivery and Therapeutics. 2022; 12(1):7-11

DOI: http://dx.doi.org/10.22270/jddt.v12i1.5266

\section{*Address for Correspondence:}

Meiyanti, Department of Pharmacology and Medical Pharmacy, Faculty of Medicine, Universitas Trisakti, Jakarta, Indonesia.

ORCID ID: https://orcid.org/0000-0002-1770-5504

\section{Abstract}

The long-term use of some drugs causes side effects in the form of elevated liver enzyme levels. Meanwhile, antipsychotic drug therapy in people with mental disorders induces liver injury which leads to an elevation in serum glutamic oxaloacetic and pyruvic transaminases. Therefore, this study aims to analyze the relationship between the uses of antipsychotic drugs with elevated liver enzymes in people with mental disorders. This observational study used a cross-sectional design that included 69 people with mental disorders. The respondents were selected based on consecutive non-random sampling, while the data were collected using a questionnaire to obtain the universal characteristics of the subjects, therapy duration, and antipsychotic type, as well as an examination of AST and ALT levels using the ultraviolet test method. Furthermore, data analysis was conducted using the chi-Square test with a significance level of $\mathrm{p}<0.05$. The results showed that thirty-two among the respondents or $46.4 \%$ used atypical antipsychotics, while 37 or $73.0 \%$ received the drugs for 1-6 months. In the subjects receiving typical antipsychotics, 10 or $55.6 \%$ had a significant elevation in liver enzymes compared to others receiving atypical antipsychotics namely $6(18.8 \%)$ or a combination of both drugs namely $6(31.6 \%)$. Therefore, the type of antipsychotic used in therapy has a significant relationship with elevated liver enzymes in people with mental disorders $(\mathrm{p}=0.028)$.

Keywords: antipsychotics, drugs, elevated

\section{INTRODUCTION}

Serum glutamic oxaloacetic transaminase/ aspartate aminotransferase (AST) and glutamic pyruvic transaminase/ alanine transferase (ALT) are enzymes used as an indicator of liver parenchymal damage and to determine inflammation in the body. The ratio of AST to ALT is used to distinguish liver damage from other organs and observe its severity. ${ }^{1}$ The liver is the main organ for drug metabolism. Adverse reactions to drugs can cause drug-induced liver injury (DILI). DILI can be asymptomatic in the form of abnormalities in several liver function tests (prothrombin time, albumin, bilirubin, AST, ALT) or symptomatic with clinical manifestations in the form of acute liver disease, prolonged jaundice as well as acute or subacute liver failure. Increased levels of both enzymes are mostly caused by acute or chronic hepatitis, liver cirrhosis, acute blockage of the bile ducts, liver obstruction, alcohol, and drugs. ${ }^{2}$ The incidence of liver damage due to drugs ranges from $1 / 10,000$ $1 / 100,000$ per year. 3 Hepatotoxicity causes various conditions such as hepatic steatosis, steatohepatitis, liver fibrosis, and even liver cirrhosis. ${ }^{4}$ Meanwhile, one or other of the drugs that induce liver injury is antipsychotics as demonstrated by previous studies which stated that the prevalence of elevated AST and ALT levels due to antipsychotic medication is $7 \% .5$

Antipsychotics are first-line therapy effective in patients with schizophrenia and other primary psychotic disorders.
Some antipsychotics are also used to treat bipolar disorder, depression, autism, or Tourette's disorder. This treatment aims to reduce the effects of hallucinations and delusions, as well as improve disorganized thinking and behavior. Antipsychotic therapy is usually administered on a longterm basis; hence, problems arise in the treatment process. 6,7 According to WHO, half of all mental illnesses begin at the age of 14 and three-quarters in the mid-20s, while the prevalence pattern increase with increasing age, and the highest is usually found at the age of 75 years. ${ }^{8}$

Furthermore, the 2018 Basic Health Research data stated that the prevalence of severe mental disorders, such as schizophrenia in Indonesia is $7 \%$, while the prevalence in West Kalimantan is $8 \%$. The Basic Health Research also stated that the percentage of previously treated patients reached $84.9 \% .{ }^{9}$ Moreover, the prevalence of antipsychotic use was 267.1 per 100,000 subjects with almost the same number of male and female populations in the United States. 10 Several previous studies have shown that the incidence rate of elevated liver enzymes and bilirubin levels in antipsychotic users is $0.1-1 \%$ and this increase in liver enzymes occurs after administration of the drug for more than 6 weeks. 3,6

Previous studies stated the effect of antipsychotic drugs administration on high levels of AST and ALT enzymes in patients with mental disorders, and This shows that the longer the patient takes drugs for mental disorders, the 
levels of the AST and ALT enzymes in the patient will increase. ${ }^{11}$ Combination antipsychotics generation 1 and 2 are widely used to treat schizophrenia, and the highest side effect due to the use of antipsychotics is an extrapyramidal syndrome, and side effects in the form of an increase in AST and ALT the incidence is low. ${ }^{12}$ However, the results of this study are different from the other study stated that the levels of AST and ALT had no significant relationship with the duration of short and long-term antipsychotic therapy. ${ }^{13}$

Schizophrenia is included in the top 10 mental disorders that require long-term pharmacotherapy. Long-term use of antipsychotics increases the risk of drug side effects, especially DILI, but this is not routinely monitored and evaluated. Although there are few studies that have investigated the relationship between antipsychotic drugs with impaired liver function and the duration of drug use with these disorders. However, there are still many discrepancies between the use of the type, duration of antipsychotic therapy, and impaired liver function, especially the increase in AST and ALT. Therefore, this study aims to examine the prevalence of liver enzyme abnormalities, as well as the relationship between the type of antipsychotic, duration of therapy with antipsychotic, and liver enzyme AST and ALT levels in patients with mental disorders.

\section{METHOD}

This observational analytic study with a cross-sectional design approach was conducted from September to December 2020 in Singkawang City, West Kalimantan Province, Indonesia. While the inclusion criteria include inpatients with schizophrenia from adolescents to adults ranging from 15-59 years, received antipsychotic therapy for the first time, have no history of liver, kidney, others damage before drug therapy, and submitted informed consent. Meanwhile, the exclusion criteria were patients who received hepatoprotective drug therapy and consumed alcohol in the active phase. The number of samples was calculated by using the following formula

$$
\text { no }=\frac{Z \alpha^{2} \times p \times q}{d^{2}}
$$

$$
\begin{array}{ll}
\mathrm{n} & =\text { the required optimum sample } \\
\mathrm{Z} \alpha & =\text { on a significance level of } 95 \% \text {, the value is at } 1.96 \\
\mathrm{p} & =\text { prevalence of elevated liver enzymes due to the use }
\end{array}
$$
of antipsychotic drugs was $7 \%$

$\mathrm{q}=$ prevalence of subjects not suffering from the researched phenomenon $(1-p)=0.93$

$\mathrm{d}=$ accuracy of measurement is predetermined at 0.05

On a corrected finite population:

$$
\mathrm{n}=\frac{\mathrm{n}_{0}}{\left(1+\frac{\mathrm{n}_{0}}{\mathrm{~N}}\right)}
$$

$\mathrm{N}=$ number of patients with mental disorder are 147

no $\quad=$ sample size on a finite population

$\mathrm{n}=$ sample size required for a finite population

The required sample size after dropping out is $15 \%$ or 69 subjects. The sample selection was carried out by consecutive non-random sampling, this research data collection was carried out in two ways, namely collecting primary data by conducting observations and with interviews with patients and their families directly. Data collection the second is secondary data collected from the patient's medical record, in the form of complete patient data therapy duration, and a class of antipsychotic drugs used. Furthermore, blood samples were taken to assess the AST and ALT levels, while the two enzymes were examined using the Ultraviolet Test method with a photometer 4010 at a wavelength of $340 \mathrm{~nm}$.

The univariate analysis was used to describe the distribution of each variable age, gender, antipsychotic type, therapy duration, and liver enzymes AST and ALT levels. Meanwhile, bivariate analysis was conducted to examine the relationship between the antipsychotic type, therapy duration, and liver enzyme levels. The statistical test used was chi-square with a significance level of 0.05 .

The study protocols passed the ethical review from the Research Ethics Commission, Faculty of Medicine, Universitas Trisakti with No.6/KER-FK/10/2020.

\section{RESULTS}

Among the sixty-nine subjects, 39 or $57 \%$ were male and 66 or $95.65 \%$ were adults. Based on medical record data, the most widely used class of antipsychotic drugs was atypical antipsychotic drugs (generation II) as many as 32 subjects (46.4\%), and $27.5 \%$ used a combination of generation I and II antipsychotics. Based on the duration of drug use, most of the subjects $53.6 \%$ (37 subjects) had received antipsychotic therapy for 1-6 months. (Table 1).

Table 1: Characteristics of respondents $(n=69)$

\begin{tabular}{lc}
\hline Variable & N (\%) \\
\hline Gender & \\
Female & $30(43)$ \\
Male & $39(57)$ \\
Age & \\
Adolescent ( $\leq 25$ years) & $3(4.3)$ \\
Adult (> 25 years) & $66(95.7)$ \\
Antipsychotic & \\
APG I & $18(26.1)$ \\
APG II & $32(46.4)$ \\
APG I and II (combination) & $19(27.5)$ \\
Therapy Duration & \\
1-6 months & $37(53.6)$ \\
$>6$ months & $32(46.4)$ \\
Liver enzymes (AST and ALT) & \\
Normal & $47(68.1)$ \\
Abnormal & $22(31.9)$ \\
\hline
\end{tabular}

APG I: first-generation antipsychotic APG II: second-generation antipsychotic

The results of the average levels of AST and ALT were 23.64 $\mathrm{U} / \mathrm{L}$ and $22.97 \mathrm{U} / \mathrm{L}$. The highest levels of AST and ALT were $56.20 \mathrm{U} / \mathrm{L}$ and $47.49 \mathrm{U} / \mathrm{L}$. In this study, it was found that 12 of the 22 respondents who experienced abnormal levels of AST and ALT were women and the other 10 respondents were men.

In table 2, Haloperidol or chlorpromazine (group APG I) is an antipsychotic drug used for therapy. As many as 10 (55.6\%) of the 18 respondents who took haloperidol had abnormal 
AST and ALT levels. The APG II used to treat patients in this hospital is clozapine or risperidone. The incidence of elevated liver enzyme levels in subjects receiving APG II or the combination was $18.8 \%$ and $31.6 \%$, lower than subjects who received APG I. Subjects who have used antipsychotic drugs > 6 months with normal liver enzyme levels (AST and
ALT) are $20(62.5 \%)$ lower than the duration of use less than or equal to 6 months by $23(73 \%)$, but not significantly statistically $(p=0.352)$. Patients who received APG I therapy had a higher incidence of elevated liver enzymes 10 (55.6\%), and statistically significant compared to subjects who received APG II or combination therapy $(\mathrm{p}=0.028)$.

Table 2: Relationship between therapy duration and antipsychotic type with liver enzymes

\begin{tabular}{|c|c|c|c|c|}
\hline \multirow[b]{2}{*}{ Variable } & \multicolumn{3}{|c|}{$\begin{array}{l}\text { Liver Enzymes } \\
\text { (AST and ALT) }\end{array}$} & \multirow[b]{2}{*}{ p } \\
\hline & $\begin{array}{c}\mathbf{N} \\
\text { n (\%) }\end{array}$ & $\begin{array}{c}\text { AbN } \\
\text { n (\%) }\end{array}$ & $\begin{array}{l}\text { Total } \\
\text { n (\%) }\end{array}$ & \\
\hline \multicolumn{5}{|l|}{ Therapy duration } \\
\hline $1-6$ months & $\begin{array}{l}27 \\
(73)\end{array}$ & $\begin{array}{l}10 \\
(27)\end{array}$ & $\begin{array}{l}37 \\
(100)\end{array}$ & \multirow[t]{2}{*}{0.352} \\
\hline$>6$ months & $\begin{array}{l}20 \\
(62.5)\end{array}$ & $\begin{array}{l}12 \\
(37.5)\end{array}$ & $\begin{array}{l}32 \\
(100)\end{array}$ & \\
\hline \multicolumn{5}{|l|}{ Antipsychotic type } \\
\hline APG I & $\begin{array}{l}8 \\
(44.4)\end{array}$ & $\begin{array}{l}10 \\
(55.6)\end{array}$ & $\begin{array}{l}18 \\
(100)\end{array}$ & \multirow{3}{*}{$0.028^{*}$} \\
\hline APG II & $\begin{array}{l}26 \\
(81.2)\end{array}$ & $\begin{array}{l}6 \\
(18.8)\end{array}$ & $\begin{array}{l}32 \\
(100)\end{array}$ & \\
\hline APG I \&II & $\begin{array}{l}13 \\
(68.4)\end{array}$ & $\begin{array}{l}6 \\
(31.6)\end{array}$ & $\begin{array}{l}19 \\
(100)\end{array}$ & \\
\hline
\end{tabular}

\section{DISCUSSION}

The results of our study showed that the number of male schizophrenia patients was higher than that of women. This may be due to the antidopaminergic effect of estrogen in women. The hormone estrogen influences the activity of dopamine in the nucleus accumbens in the form of inhibiting the release of dopamine. The etiology of schizophrenia is an increase in the number of dopamine receptors in the caudate nucleus, accumbens, and putamen. The neuroprotective effect of the hormone estrogen will indirectly affect the onset and better course of the disease in women. ${ }^{14}$ Based on age the number of schizophrenic patients was in the adult age group 66/69 (95.7\%). This result is not different from the study in South Kalimantan where most of the schizophrenic patients were aged between 17-40 years (72.9\%). 12 The incidence of schizophrenia often occurs in late adolescence or early adulthood. This may be due to the age group entering the productive age which is filled with various stress factors. Stress trigger factors include family problems, problems with coworkers, workload, to economic problems that can affect emotional development. Stressors cause an increase in the secretion of the neurotransmitter glutamate (GABA precursor compound) in the limbic system; this causes an imbalance of neurotransmitters, which can trigger the occurrence of schizophrenia. 15

The most commonly used drugs by the respondents were atypical antipsychotics (APG II) with a total of $46.4 \%$. The use of atypical antipsychotics is preferred over typical drugs in schizophrenics because it is more effective in treating symptoms and is less likely to cause extrapyramidal and endocrine side effects which might interfere with the patient's quality of life and reduce medication adherence. 16,17 Abnormal liver enzyme levels were found in twenty-two subjects including 12 women and 10 men. This contrasts with earlier studies which stated that men experience an elevation in AST and ALT more than women. Men tend to have a habit of smoking and alcohol consumption which causes an increase in drug metabolism in the liver and leads to an elevation in AST and ALT levels. ${ }^{6}$ Smoking will increase drug metabolism in the liver. The habit of consuming alcohol in the long term can cause liver damage. The concentration of ethanol in the blood will determine the rate of metabolism in the liver by producing free radicals, acetaldehyde, increasing levels of NADH/ADH. Liver damage can be caused by the accumulation of acetaldehyde in the liver. ${ }^{18}$ However, it is undeniable that women nowadays might also have a habit of smoking and alcohol consumption.

The prevalence of abnormal liver function found in this study is $31.9 \%$. Most studies have found a greater prevalence of elevated liver enzymes than the $2.5 \%$ predicted by the reference range design. The percentage range of patients with abnormal liver enzyme elevations ranged from $5-78 \%$, with a median value of $32 \%$. ${ }^{19}$ This result is higher than the study in South Kalimantan, the rate of increase in liver enzymes was only $1.7 \%$, and the most side effects found in antipsychotic users were extrapyramidal syndrome and orthostatic hypotension. ${ }^{12}$ In general, there are three mechanisms of liver damage by drugs namely hepatocellular, cholestatic, and mixed types 
(hepatocellular and cholestatic). Hepatocellular type is the primary side effect involving hepatocytes when the drug or drug metabolite binds to cellular liver proteins or macromolecules. It is usually characterized by elevated levels of AST and ALT. This condition also allows an increase in bilirubin and alkaline phosphatase. Cholestasis is the result of the binding of drugs or drug metabolites to proteins in the canalicular membrane leading to ductal damage with increased alkaline phosphatase and bilirubin. In the mixed type, it is a combination of hepatocellular damage and cholestatic mechanisms characterized by an increase in ALT and alkaline phosphatase. Direct hepatotoxicity is direct liver damage caused by drug metabolites. This state is influenced by the dose of the drug, is predictable, and is referred to as an intrinsic process. Direct hepatotoxicity can induce liver damage through immune and inflammatory responses. 6,19

The data showed that type antipsychotic drugs had a significant relationship with abnormal/elevated AST and ALT levels. This result is in line with Tiara et al. which stated that antipsychotic administration had a significant effect on AST and ALT. 11 The first-generation antipsychotic (APG I) used in this study was haloperidol where 10 out of 18 respondents taking this drug experienced abnormal AST and ALT. Satya et al. reported that a patient showed clinical symptoms of jaundice after three weeks of haloperidol administration. ${ }^{20}$ The toxicity mechanism of this drug is like phenothiazines which cause cholestasis and is associated with immune-mediated hypersensitivity. Meanwhile, the gradual accumulation of cholestasis causes a direct toxic effect that might attack hepatocytes. ${ }^{8,21}$

APG I and APG II affect different genes and biologics in the liver. APG I affects genes related to nuclear proteins, stress response and phosphorylation, whereas APG II affects genes related to endoplasmic reticulum and cytoplasmic transport. Based on the research conducted, it is known that APG II has lower toxicity than APG I due to different gene expression patterns. ${ }^{16}$ However, Pauline et al. stated that elevated liver enzymes are more common with clozapine and olanzapine compared to risperidone and haloperidol.22 The different mechanisms of hepatotoxicity are not currently known, but the mechanism of hypersensitivity is most likely dosedependent. The occurrence of this hypersensitivity through an immuno-allergic mechanism causes cholestatic lesions which are usually not clinically significant. ${ }^{22,23}$

The data showed that the antipsychotic therapy duration 1-6 months and $>6$ months did not have a significant relationship with AST and ALT levels. This is consistent with Cahyaningtyas et al. ${ }^{13}$ which stated that there was no significant relationship between the duration of short-term ( $\leq 6$ months) and long-term ( $>6$ months) combination of antipsychotic therapy with AST and ALT levels. ${ }^{18}$. Most antipsychotic drugs are metabolized in the liver via the cytochrome P450 (CYP) system is metabolized primarily by the combination of CYP2D6 and CYP3A4, although clozapine and olanzapine are predominantly metabolized via CYP1A2. Variation CYP enzyme isoforms for drug metabolism can lead to different possibilities of drug-drug interactions and pharmacogenetic effects, and possible risk of liver injury. ${ }^{20-}$ 22 Research results by Wafeck et al. stated that there was no significant difference between the first time and after 6 months of using class I or II antipsychotics. This is likely because the hepatic damage may disappear. The existence of an adaptive change process in hepatocytes that involves the regulation of antioxidant genes or chaperone proteins can be considered as a cause. ${ }^{24}$ The minimum time reported until the onset of abnormalities was 1 week, and most abnormalities occurred within 6 weeks. This is presumably due to the process of adaptive changes in hepatocytes involving the regulation of antioxidant genes or chaperone proteins. Other risk factors that cause AST and ALT abnormalities are obesity and the use of addictive substances. ${ }^{19,25}$ In the presence of elevated liver enzymes, some studies have discontinued therapy or continued with lower doses or even higher doses. Liver function abnormalities did not worsen despite continued treatment. In general, liver function will improve in about 1 month. ${ }^{19}$

This study still has limitations; hence, there is a need to consider other factors such as body mass index, history of using addictive drugs, smoking habits, and consumption of alcohol or other hepatotoxic drugs which might affect the liver enzyme levels.

Based on the results, the antipsychotic type has a significant relationship with elevated liver enzyme levels, but the therapy duration had no significant relationship.

\section{Conflict of Interest:}

The investigators declare there is no conflict of interest in this study.

\section{Acknowledgments:}

The authors are grateful to all doctors and staff of the Mental Hospital of West Kalimantan Province, laboratory staff, and all subjects that took part in this study.

\section{REFERENCES}

1. Chloe MM. Biochemical diagnosis of Wilson disease. clinical translational perspectives on Wilson disease, 2019; 237-48. https://doi.org/10.1016/B978-0-12-810532-0.00021-5

2. Vukotic NT, Dordevic J, Pejic S, Dordevic N, Pajovic SB. Antidepressant- and antipsychotics- induced hepatotoxicity. Archives of Toxicology, 2021; 95:767-89. https://doi.org/10.1007/s00204-020-02963-4

3. Qinyu LV, Zhenghui YI. Antipsychotic drugs and liver injury. Shang Arch Psych, 2018; 30(1):47-51. https://doi.org/10.11919/j.issn.1002-0829.217090

4. Aithal GP, Watkins PB, Andrade RJ et al. Case definition and phenotype standardization in drug-induced liver injury. Clin Pharmacol Ther 89:806-815. https://doi.org/10.1038/clpt.2011.58

5. Zaini S, Ahmad NA. Chronic liver disease in patients with schizophrenia: a review. Malays J Psychiatry. 2018; 27(2):1-12.

6. López-Torres E, Süveges A, Peñas-Lledó EM, Doña A, Dorado P, Llerena A, et al. Liver enzyme abnormalities during antipsychotic treatment: a case report of risperidone associated hepatotoxicity. Drug Metabol Drug Interact, 2014; 29(2); 123-6. https://doi.org/10.1515/dmdi-2013-0064

7. Julaeha, Ananda V, Pradana D. Overview of antipsychotic side effects in schizophrenic patients in an inpatient ward at Grhasia Hospital, Yogyakarta. Farmasains, 2016; 3(1):35-41

8. World Health Organization. Adolescent Mental Health 2019. Available from: https://www.who.int/news-room/factsheets/detail/adolescent-mental-health

9. Kementerian Kesehatan Republik Indonesia. Riskesdas 2018. Available from: https://www.kemkes.go.id/resources/download/infoterkini/hasil-riskesdas-2018.pdf

10. Curtis LH, Masselink LE, ØstbyeT, Hutchison S, Dans pe, Wright A, et al. Prevalence of atypical antipsychotic drug use among commercially insured youths in The United States. Arch Pediatr Adolesc Med, 2005; 159:362-6.

https://doi.org/10.1001/archpedi.159.4.362

11. Anjelisa T, Ruhi S. Pengaruh pemberian obat terhadap tingginya kadar enzim serum glutamate oksaloasetat transaminase (SGOT) dan serum glutamate piruvat transaminase (SGPT) pada 
pasien gangguan jiwa di RS Jiwa Provinsi Sulawesi Tenggara Jurnal MediLab Mandala Waluya Kendari. 2018; 2(1):49-52.

12. Yulianty MD, Cahaya N, Srikartika VM. Antipsychotics use and side effects in patients with schizophrenia at Sambang Lihum Hospital South Kalimantan, Indonesia. Jurnal Sains Farmasi dan Klinis. 2017; 3(2):153-64.

https://doi.org/10.29208/jsfk.2017.3.2.108

13. Cahyaningtyas, Rahmatini, Sedjahtera K. Hubungan Lama Terapi Antipsikotk dengan Kadar SGOT dan SGPT pada Pasien

Skizofrenia di RSJ Prof. H. B Sa'anin Padang Tahun 2013. Jurnal Kesehatan Andalas. 2017; 6(1):128-33.

https://doi.org/10.25077/jka.v6i1.658

14. Canuso CM, Pandina G. Gender and schizophrenia. Psychopharmacol Bull, 2007; 40(4):178-90.

15. Jarut YM, Fatimawati, Wiyono IW. Tinjauan penggunaan antipsikotik pada pengobatan skizofrenia di rumah sakit Prof.dr.V.I Ratumbuysang Manaso periode Januari 2013-Maret 2013. Pharmacon, 2013; 2(3):54-7. https://doi.org/10.35799/pha.2.2013.2378

16. Choi KH, Higgs BW, Weis S, Song J, Llenos K, Dulay JR, et al. Effects of typical and atypical antipsychotic in the liver of schizophrenia subjects. BMC Psychiatry, 2009; 9:57. https://doi.org/10.1186/1471-244X-9-57

17. Joseph N (2021) Antipsychotics advantages, disadvantages and treatment. J Bioequiv Availab. s1: e001

18. Indira H, Sudayasa IP, Uddu WSS, Imran M, Yakin A. Pengaruh minuman tradisional komeko terhadap kadar SGOT, SGPT, dan jaringan hati mencit (Mus musculus). Pharmauho, 2017; 4(1):23-5. http://dx.doi.org/10.33772/pharmauho.v3i1.3449
19. Marwick K, Walker SW, Taylor M. Antipsychotics and abnormal liver function tests: a systematic review. Clin Neuropharm, 2012; 35(5):244-53.

https://doi.org/10.1097/WNF.0b013e31826818b6

20. Dutta SK, Chakravarty PJ, Borah AJ. A Case Report on haloperidol-induced hepatotoxicity. Ann Psychiatr Clin Neurosci, 2020; 3(1):1-3

21. Correia DT, Barbosa A, Pinto HC, Compos C, Rocha NBF, Machado S. Psychotropic drugs and liver disease : a critical review of pharmacokinetics and liver toxicity. World J Gastrointest Pharmacol Ther, 2017; 8(1):26-38. https://doi.org/10.4292/wjgpt.v8.i1.26

22. Manceaux P, Constant E, Zdanowicz N, Jacques D, Reynaert C. Management of marked liver enzymes increases during olanzapine treatment: a case report and review of the literature. Psychiatry Danubina, 2011; (23):15-17

23. Correia DT, Barbosa A, Pinto HC, Compos C, Rocha NBF, Machado S. Psychotropic drugs, and liver disease: a critical review of pharmacokinetics and liver toxicity. World J Gastrointest Pharmacol Ther. 2017; 8(1):26-38. https://doi.org/10.4292/wjgpt.v8.i1.26

24. El Sheikh WM, Rajab AZ, Shalaby AS, Shaheen AG. Comparison between typical and atypical antipsychotics according to their effects on metabolism in schizophrenia patients. Menofia Med J, 2019; 32(1):80-7. https://doi.org/10.4103/mmj.mmj_645_17

25. Pandit A, Sachdeva T, Bafna P. Drug-induced hepatotoxicity: a review. J Appl Pharm Sci. 2012; 2(5)233-43. https://doi.org/10.7324/JAPS.2012.2541 